\title{
Residual renal function assessment with cystatin $\mathbf{C}$
}

\author{
Guido Filler • Shih-Han S. Huang • Robert M. Lindsay
}

Received: 8 September 2010 /Accepted: 9 September 2010 /Published online: 7 November 2010

(C) IPNA 2010

\begin{abstract}
Su Jin Kim and coworkers from Korea published an important study on the relationship of residual renal function (RRF) and cystatin in pediatric peritoneal dialysis (PD) patients in this issue of Pediatric Nephrology, both in anuric patients and patients with RRF. Based on a lack of correlation between cystatin $\mathrm{C}$ and standard small solutebased dialysis adequacy parameters such as $\mathrm{Kt} / \mathrm{V}_{\text {urea }}$ but a significant correlation with RRF, the authors concluded that cystatin $\mathrm{C}$ may be a good tool to monitor RRF. The editorial reviews the available literature in adults, the different handing between urea and cystatin $\mathrm{C}$, and the determinants of cystatin $\mathrm{C}$ clearance in dialysis patients. In adults, cystatin $\mathrm{C}$ levels are determined predominantly by RRF, but not exclusively. In anephric hemodialysis and PD patients, there is a correlation with standard weekly $\mathrm{Kt} / \mathrm{V}_{\text {urea }}$. Cystatin $\mathrm{C}$ levels will also depend on ultrafiltration. Despite these factors that affect cystatin $\mathrm{C}$ levels beyond RRF, cystatin $\mathrm{C}$ is a useful parameter for monitoring PD patients that may be more closely related to long-term outcomes than small solute adequacy parameters.
\end{abstract}

\section{G. Filler}

Division of Nephrology, Department of Pediatrics,

The University of Western Ontario,

London, Ontario, Canada

S.-H. S. Huang • R. M. Lindsay

Nephrology Division, Department of Medicine,

The University of Western Ontario,

London, Ontario, Canada

\section{G. Filler $(\square)$}

Department of Pediatrics,

800 Commissioners Road East,

London, Ontario N6A 5W9, Canada

e-mail: guido.filler@1hsc.on.ca
Keywords Cystatin C · Residual renal function · Peritoneal dialysis $\cdot$ Hemodialysis $\cdot$ End-stage renal disease .

Ultrafiltration

\section{Introduction}

Practicing pediatric nephrologists have felt for some time that prescribing more dialysis should improve outcomes. In adults, the result of the National Cooperative Dialysis Study showed a survival benefit with increased dialysis prescription [1]. Disappointingly, no survival benefits with further increase in small solutes clearances once a certain threshold level was reached, which were demonstrated in two major adult trials: the Effects of Increased Peritoneal Clearances on Mortality Rates in Peritoneal Dialysis: ADEMEX, a Prospective, Randomized, Controlled Trial (ADEMEX) and the Effect of Dialysis Dose and Membrane Flux in Maintenance Hemodialysis (HEMO) studies [2, 3]. However, residual renal clearance as the major predictor of survival in dialysis patients (both hemodialysis and peritoneal dialysis) was demonstrated in carefully conducted re-analyses of both studies [4, 5]. As a result, it is important to monitor and to preserve residual renal function (RRF) in dialysis patients, as it is a strong predictor for patient survival in this adult population and presumably also in children. The Kidney Disease Outcomes Quality Improvement (KDOQI) clinical practice guideline recommends monitoring of RRF periodically in patients with end-stage renal disease [6].

As pointed out in the study from $\mathrm{Su}$ Jin Kim and coworkers from Korea [7] in this issue of Pediatric Nephrology, goldstandard measurements of RRF using inulin clearance or nuclear medicine techniques such as ${ }^{99} \mathrm{Tc}$ DTPA or ${ }^{51} \mathrm{Cr}$ EDTA clearance studies are cumbersome and invasive. In 
clinical practice, renal $\mathrm{Kt} / \mathrm{V}_{\text {urea }}$ are utilized in pediatric dialysis patients, but unreliable collection of urine and peritoneal dialysis fluid frequently skew results and provide inadequate estimates of RRF.

Recent adult studies in adult dialysis patients suggest that cystatin $\mathrm{C}$ levels reflect predominantly (but not exclusively) renal clearance independent of urine collection, making this an attractive marker for assessment of RRF $[8,9]$. Cystatin $\mathrm{C}$ values also correlated inversely to weekly creatinine clearance and to total [peritoneal dialysis (PD) + residual renal function] $\mathrm{Kt} / \mathrm{V}_{\text {urea }}$. Multiple regression models showed that only the renal components of $\mathrm{Kt} /$ $\mathrm{V}_{\text {urea }}$ and weekly creatinine clearance contributed to the serum cystatin $\mathrm{C}$ concentrations. A further study by Hoek and colleagues [10] also showed that a modeled formula from plasma cystatin $\mathrm{C}$ levels showed better accuracy and precision than the estimated residual glomerular filtration rate (GFR) obtained with the modification of diet in renal disease (MDRD) formula. In this study, cystatin C levels were taken from 215 hemodialysis and 95 chronic ambulatory peritoneal dialysis patients to derive the formula for RRF. The formula was then tested in a validation group of 107 hemodialysis and 48 peritoneal dialysis patients. The Hoek study [10] did not address the contribution of dialytic clearance whether by hemodialysis (HD) or PD to the plasma cystatin C levels. Dialytic clearance must have an effect on cystatin $\mathrm{C}$ concentrations: cystatin $\mathrm{C}$ is a cysteine protease inhibitor and a lowmolecular-weight protein $(13.2 \mathrm{kDa})$ produced at a constant rate by all nucleated cells [11]. Cystatin $\mathrm{C}$ would be affected by dialytic clearance just like the low-molecularweight protein beta-2 microglobulin, albeit less in PD patients than in high-flux hemodialysis patients [12]. Beta-2 microglobulin is commonly monitored in dialysis patients because of its known associated morbidity, especially with regards to amyloidosis [13].

In a recent study, Al Malki et al. [14] included functionally anephric patients on conventional $(3-5 \mathrm{~h}$, three times/week) hemodialysis, nocturnal hemodialysis (3-7 nights, $6-8 \mathrm{~h}$ ), daily hemodialysis (6 days, 1.5-2.5 h) and automated peritoneal dialysis and studied cystatin $\mathrm{C}$ levels. The serum cystatin $\mathrm{C}$ levels were compared with urea kinetic studies that included single pool $\mathrm{Kt} / \mathrm{V}_{\text {urea }}$ and standard weekly $\mathrm{Kt} / \mathrm{V}_{\text {urea. }}$. It was found that the cystatin $\mathrm{C}$ levels were indeed influenced by the method and intensity of dialysis, and did show a significant negative correlation with the standard weekly $\mathrm{Kt} / \mathrm{V}_{\text {urea }}$. The regression equation indicated that for every increase in cystatin $\mathrm{C}$ of $1 \mathrm{mg} / \mathrm{l}$, the standard weekly Kt/V had decreased by 0.703 . Because of this, patients who were treated by nocturnal or daily hemodialysis had statistically significantly lower mean cystatin $\mathrm{C}$ levels than the conventional hemodialysis and automated peritoneal dialysis groups. It was of interest that the cystatin $\mathrm{C}$ level was not correlated with the single treatment, single pool $\mathrm{Kt} / \mathrm{V}_{\text {urea }}$. This study suggests that cystatin $\mathrm{C}$ is dialyzable and that its serum or plasma concentration will be dependent upon the balance between its weekly generation and dialytic clearance together with its volume of distribution. It is possible that the volume of distribution, being a small molecular weight protein, is confined to the extracellular space. Further studies are therefore needed in anephric patients to examine the changes in serum or plasma cystatin $\mathrm{C}$ levels over the course of a number of individual hemodialysis or peritoneal dialysis treatments and of the time-course of serum or plasma cystatin concentrations following a change in dialysis modality intensity. Comparisons of changes in serum or plasma cystatin $\mathrm{C}$ levels to a small molecular weight surrogates such as urea should answer these questions.

Cystatin C levels appear fairly stable in the dialysis population and perhaps depend upon the certain consistency of dialysis dose over time rather than be influenced by a single treatment [14]. The fact that cystatin $C$ concentration is not influenced by the single pool $\mathrm{Kt} / \mathrm{V}$ supports this concept. It may be that the cystatin C level and single pool Kt $/ \mathrm{V}_{\text {urea }}$ in a dialysis patient is somewhat analogous to the hemoglobin A1C level in its relationship to plasma glucose value in the diabetic. In other words, the marker may reflect cumulative middle molecule clearance over time. The stability may be useful in that a given cystatin $C$ level may allow the rough estimation of both dialytic and residual renal functional clearance, providing the total standard weekly $\mathrm{Kt} / \mathrm{V}_{\text {urea }}$ is known.

Studies in children remain scarce. With this context, we read the Korean study on pediatric PD patients [7] with great interest. In this study, nine patients who were anuric did not demonstrate any correlation between the peritoneal $\mathrm{Kt} / \mathrm{V}_{\text {urea }}$ or the peritoneal weekly creatinine clearance. The total $\mathrm{Kt} / \mathrm{V}_{\text {urea }}$ was within a very narrow range in this group $(1.8-2.5)$. By contrast, the total weekly creatinine clearance was 49.8 (range 36.2-66.3) L/week/1.73 $\mathrm{m}^{2}$, suggesting a much wider range of dialysis prescriptions than indicated by the total $\mathrm{Kt} / \mathrm{V}_{\text {urea }}$. For all patients, 24-h urine and dialysate collections were performed at home, but in the anuric group no collections were performed. Data on the proportion of the nine patients who had both native kidneys removed were not provided. By contrast, in the patients with RRF, there was a significant negative correlation between the cystatin $\mathrm{C}$ concentrations and the renal $\mathrm{Kt} / \mathrm{V}_{\text {urea }}$ $(r=-0.793, p<0.001)$. The authors concluded that serum cystatin $\mathrm{C}$ could be an appropriate marker for RRF, independent of total and peritoneal $\mathrm{Kt} / \mathrm{V}_{\text {urea }}$.

Based on their observations, this conclusion is reasonable. However, it is more likely that cystatin $\mathrm{C}$ levels are somewhat affected by dialysis dose, as the determinants of cystatin $\mathrm{C}$ concentrations during dialysis remain to be fully established. 
It is known that the intra-patient variability of cystatin $C$ levels is less than that of creatinine in children with CKD [15]. In a recent study on 15 functionally anephric patients who underwent cystatin $\mathrm{C}$ profiling during high-flux hemodialysis, we established that cystatin $\mathrm{C}$ reduction ratio depended on normalized blood liters processed and fluid removal during hemodialysis. Those two parameters explained $81 \%$ of the cystatin $\mathrm{C}$ variance. As outlined above, cystatin $\mathrm{C}$ values will be affected by volume status because of the smaller volume of distribution of cystatin $\mathrm{C}$. In contrast to creatinine, cystatin $\mathrm{C}$ is distributed only extracellular. The study by Kim et al. [7] did not consider ultrafiltration in their model. Further studies into serum cystatin $\mathrm{C}$ levels across dialysis and its appearance in dialysate are indicated, as are further studies in dialysis patients who have residual renal function [16]. The potential exists that serum cystatin $\mathrm{C}$ measurements may be valuable for the monitoring of residual renal function and delivered dialysis intensity plus the overall adequacy of uremia management provided. This is particularly important in view of the emerging importance of cystatin $\mathrm{C}$ as a marker for pre-timely mortality [17].

\section{References}

1. Lowrie EG, Laird NM, Parker TF, Sargent JA (1981) Effect of the hemodialysis prescription of patient morbidity: report from the national cooperative dialysis study. N Engl J Med 305:1176-1181

2. Eknoyan G, Beck GJ, Cheung AK, Daugirdas JT, Greene T, Kusek JW, Allon M, Bailey J, Delmez JA, Depner TA, Dwyer JT, Levey AS, Levin NW, Milford E, Ornt DB, Rocco MV, Schulman G, Schwab SJ, Teehan BP, Toto R, Hemodialysis (HEMO) Study Group (2002) Effect of dialysis dose and membrane flux in maintenance hemodialysis. N Engl J Med 347:2010-2019

3. Paniagua R, Amato D, Vonesh E, Correa-Rotter R, Ramos A, Moran J, Mujais S, Mexican Nephrology Collaborative Study Group (2002) Effects of increased peritoneal clearances on mortality rates in peritoneal dialysis: ADEMEX, a prospective, randomized, controlled trial. J Am Soc Nephrol 13:1307-1320

4. Bargman JM, Thorpe KE, Churchill DN (2001) Relative contribution of residual renal function and peritoneal clearance to adequacy of dialysis: a reanalysis of the CANUSA Study. J Am Soc Nephrol 12:2158-2162
5. Termorshuizen F, Dekker FW, van Manen JG, Korevaar JC, Boeschoten EW, Krediet RT (2004) Relative contribution of residual renal function and different measures of adequacy to survival in hemodialysis patients: an analysis of the Netherlands Cooperative Study on the Adequacy of Dialysis (NECOSAD)-2. J Am Soc Nephrol 15:1061-1070

6. National Kidney Foundation (2006) 2006 updates clinical practice guidelines and recommendations. Hemodialysis adequacy, peritoneal dialysis adequacy and vascular access. Am J Kidney Dis 48(suppl 1): S1-S322

7. Kim SJ, Sohn YB, Park SW, Jin DK, Paik KH (2010) Serum cystatin $\mathrm{C}$ for estimation of residual renal function in children on peritoneal dialysis. Pediatr Nephrol. doi:10.1007/s00467-010$1678-8$

8. Delaney MP, Stevens PE, Al Hasani M, Stowe HJ, Judge C, Lamb EJ (2008) Relationship of serum cystatin C to peritoneal and renal clearance measures in peritoneal dialysis: a cross-sectional study. Am J Kidney Dis 51:278-284

9. Ros S, Bajo A, del Peso G, Garcia de Miguel A, Santacruz S, Fernandez E, de Garcia R, Selgas R (2007) Cystatin C as marker of residual renal function in patients on peritoneal dialysis: relations with parameters of peritoneal function. J Nephrol 20:468-473

10. Hoek FJ, Korevaar JC, Dekker FW, Boeschoten EW, Krediet RT (2007) Estimation of residual renal glomerular filtration rate in dialysis patients from the plasma cystatin C level. Nephrol Dial Transplant 22:1633-1638

11. Filler G, Bökenkamp A, Hofmann W, Le Bricon T, Martínez-Brú C, Grubb A (2005) Cystatin C as a marker of GFR-history, indications, and future research. Clin Biochem 38:1-8

12. Evenepoel P, Bammens B, Verbeke K, Vanrenterghem Y (2006) Superior dialytic clearance of beta(2)-microglobulin and p-cresol by high-flux hemodialysis as compared to peritoneal dialysis. Kidney Int 70:794-799

13. Jadoul M, Garbar C, Vanholder R, Sennesael J, Michel C, Robert A, Noël H, van Ypersele de Strihou C (1998) Prevalence of histological beta2-microglobulin amyloidosis in CAPD patients compared with hemodialysis patients. Kidney Int 54:956-959

14. Al-Malki N, Heidenheim PA, Filler G, Yasin A, Lindsay RM (2009) Cystatin C levels in functionally anephric patients undergoing dialysis: the effect of different methods and intensities. Clin J Am Soc Nephrol 4:1606-1610

15. Sambasivan AS, Lepage N, Filler G (2005) Cystatin C intrapatient variability in children with chronic kidney disease is less than serum creatinine. Clin Chem 51:2215-2216

16. Lindsay RM, Huang SH, Filler G (2010) Cystatin C measurements in the assessment of residual renal function, dialysis adequacy, and beyond. Perit Dial Int 30:437-439

17. Hansson LO (2010) Cystatin C: an emerging marker for pre-timely mortality. J Intern Med 268:106-108 